\title{
Transatlantica
}

Revue d'études américaines. American Studies Journal

\section{A Weltian Rhapsody: Paul Strand, "Blind" (1917) and Eudora Welty, "Blind Weaver on the WPA, Oktibbeha County, 1930s"}

One Time, One Place, p. 27

\section{Géraldine Chouard}

\section{Q OpenEdition}

\section{Journals}

Electronic version

URL: https://journals.openedition.org/transatlantica/4696

DOI: $10.4000 /$ transatlantica.4696

ISSN: $1765-2766$

Publisher

Association française d'Etudes Américaines (AFEA)

\section{Electronic reference}

Géraldine Chouard, "A Weltian Rhapsody: Paul Strand, "Blind" (1917) and Eudora Welty, "Blind Weaver on the WPA, Oktibbeha County, 1930s'"', Transatlantica [Online], 2 | 2009, Online since 02 February 2010, connection on 31 January 2023. URL: http://journals.openedition.org/transatlantica/4696 ; DOI: https://doi.org/10.4000/transatlantica.4696

This text was automatically generated on 31 January 2023.

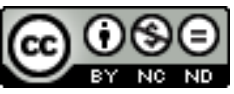

Creative Commons - Attribution-NonCommercial-NoDerivatives 4.0 International - CC BY-NC-ND 4.0 https://creativecommons.org/licenses/by-nc-nd/4.0/ 


\title{
A Weltian Rhapsody: Paul Strand, "Blind" (1917) and Eudora Welty, "Blind Weaver on the WPA, Oktibbeha County, 1930s"
}

One Time, One Place, p. 27

\author{
Géraldine Chouard
}

1 There are few photographs of blind people in the repertoire of American photography. One of the most famous is "Blind" (1917) by Paul Strand (which is part of the permanent collection of the Metropolitan Museum of Art in New York). It is a photograph of a blind woman taken on the street in New York City. This woman is a beggar. Around her neck just below a pin bearing her license number, she is wearing a placard spelling out her blindness, which allows her to beg: this was the Progressive Era, when begging on the streets required a license. This labeling system was a way to control the outcasts of society by clearly identifying them for all to see. Once she was officially certified as being blind, this woman could be the legitimate object of the public's pity. Passersby literally could not remain blind to her blindness and would no doubt give her a coin.

2 This image represents a historical moment. The genre of the photograph is reminiscent of the late 19th century anthropometric classification pictures that sought to establish general profiles based on the morphology of individuals. Even before she is a woman, this woman is, first and foremost, a blind person.

3 The frontal character of the pose is striking. In fact, this pose is the result of a type of special effect, more specifically of a trompe-l'oeil. Strand used a large-format camera fitted with a trick lens and a right-angle mirror. At the time, it was considered a modern photographic technique and was used for "Straight Photography", whose goal was to be as objective as possible. Equipped with this camera, Strand could take frontal shots of people without their knowing they were being photographed, whether they were blind or not. With this image of the blind woman, the method either cancels itself 
out or duplicates, becoming a sort of meta-image, which reflects the very practice of the photographer. By taking a picture of this woman who could not see, he stole her blind woman's gaze. Partly, at least, because from the corner of her left eye, she seems to surreptitiously resist the taking of her own picture.

Welty's photograph, "Blind Weaver on the WPA" (1930s) is, in a way, the symmetrical opposite of Strand's photo.

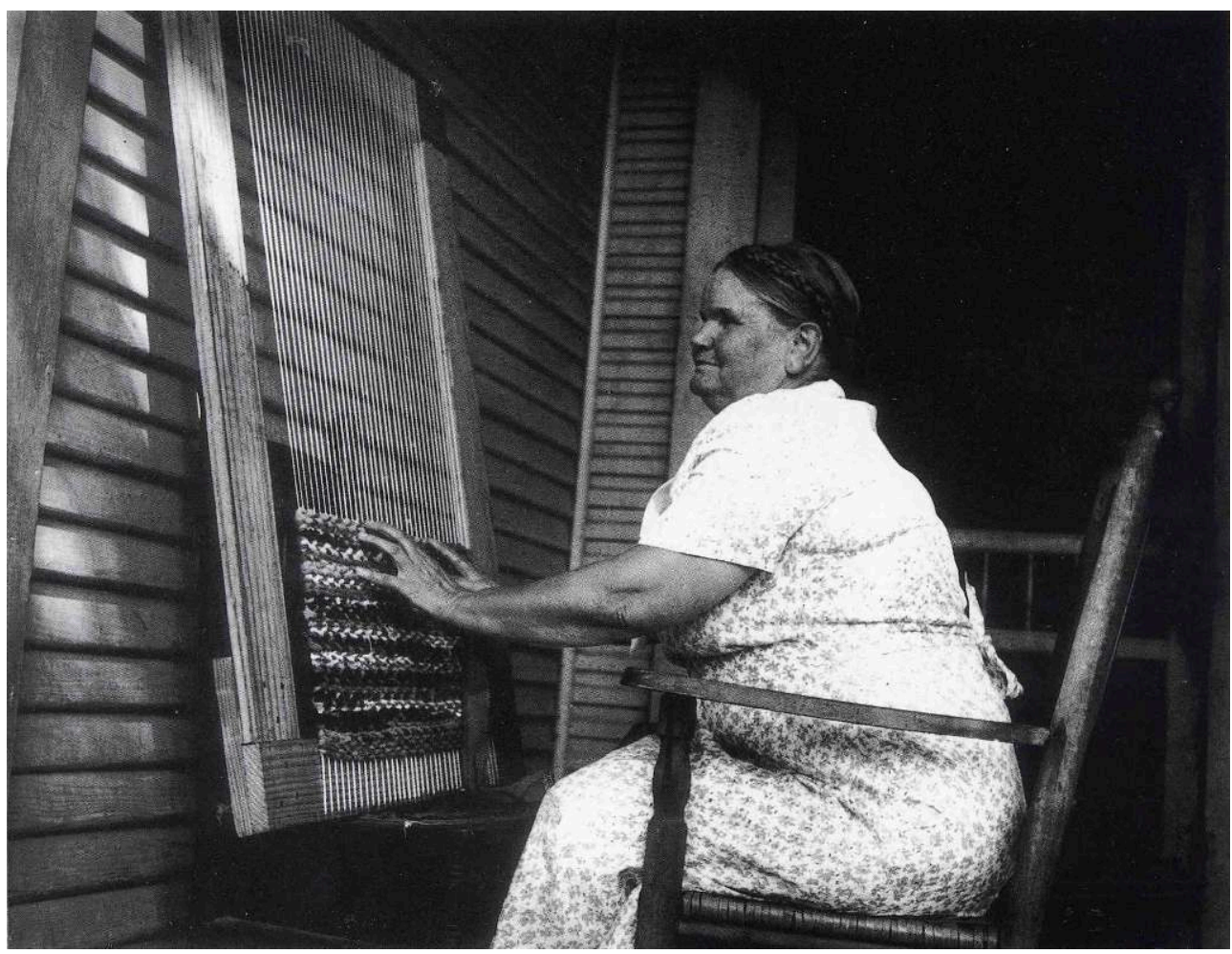

"Blind Weaver on the WPA, Oktibbeha County, 1930s," One Time, One Place, p. 27, reprinted with the gracious permission of the Eudora Welty Foundation

5 The blind woman is photographed from the side, and, at first glance, one would hardly know she is blind. In any case, nothing indicates her blindness except the caption that Welty added years later in 1971 when she published her album One Time, One Place: Mississippi in the Depression, "Blind Weaver on the WPA". Instead of a tag around her neck, another object, or rather a tool, can be seen at the tip of her fingers: a loom. The woman is not looking at the photographer, but the viewer gets the sense that she is aware of her presence. On the one hand, we know that Welty used a Leica camera where the viewfinder was placed in front of her, below her eyes. She had thus adopted the habit of never looking directly at her subject but unlike Strand, she always asked permission to take a picture. On the other hand, flipping through Weltian portraits of men and women in their surroundings, engaged in their daily activities ("Boiling Pot/ Hinds County/ 1930s" [P 21], "Hog-killing time. Hinds County/1930s" [P 32], "Making Cane Syrup/ Madison County/ 1930s" [P 33], "Hairdressing/ Jackson/ 1930s" [P 40]), one may deduce the woman knew Welty was there.

6 Times changed and so did photography.

7 During the 1930s, as part of the social programs of the FSA and WPA, photographic reporting began to take stock of places, capturing people in their daily practices. Arthur Rothstein and Marion Post Wolcott thus photographed women seated in front of 
sewing machines making quilts in Gee's Bend (Alabama) as a way to highlight traditional domestic activities and encourage women to continue their needlework. Beyond the documentary nature of these social images, they also aim at finding solutions during a time of crisis.

Welty, who was a junior publicity agent for the WPA, was aware of this prevailing discourse, and she regularly integrated subjects of her photographs into their environment. Far from begging in the street, this woman is part of the social fabric through her work, or at least her occupation, that she seems to be conducting from home. Her stout silhouette is comparable to that of Strand's blind woman, making her a descendant of the registered beggar woman in New York who ended up finding her place somewhere, providing a fine example of "getting in the picture," as the saying goes. The composition, with the vertical lines of the warp crossing the horizontal lines of the weft against the wooden planks of the house, set her and her weaving in an orthonormal frame of simple geometric beauty, reminiscent of other abstract compositions by Strand, to which Welty adds depth of perspective. This third dimension is, in itself, a way to inscribe the blind woman in space (a Southern porch) and history (her own). This blind woman is no longer a statistic, she is a weaver who is weaving her destiny in her own hands, in an age-old tradition that goes back to Penelope, if not further.

movement of her slender fingers running skilfully across her work-in-progress gives the image its unique quivering. The blind weaver is sitting at her loom as at the keys of a piano, perhaps foretelling Miss Eckhart, the formidable woman of The Golden Apples (1949). Whether playing the piano or weaving, strings are involved, where the rhapsos of music and sewing join together.

From this superb performance in Braille, the distant vibrant notes of the vast Weltian rhapsody rise up. To hear them, one must only open one's eyes.

\section{BIBLIOGRAPHY}

WELTY, Eudora, One Time, One Place: Mississippi in the Depression. University Press of Mississippi, 1971.

WELTY, Eudora, Photographs. University Press of Mississippi, 1989.

\section{INDEX}

Subjects: Trans'Arts 
AUTHOR

GÉRALDINE CHOUARD

Université Paris-Dauphine 